\title{
Productivity Analysis and Welfare of Salt Farmers in Tanoh Anoe Village,Bireun-Indonesia
}

\author{
Rahmad Sembiring ${ }^{1 *}$, Annisa Ilmi Faried ${ }^{2}$ \\ \{rahmatsembiring2@gmail.com¹, annisailmi@dosen.pancabudi.ac.id²\} \\ ${ }^{1}$ Universitas Sumatera Utara, Medan, Indonesia \\ ${ }^{2}$ Universitas Pembangunan Panca Budi, Medan, Indonesia \\ rahmatsembiring2@gmail.com
}

\begin{abstract}
The purpose of this study is to identify the factors that influence the productivity and welfare of salt farmers in Tanoh Anoe Village, Kecamatan Term Bireun-Aceh District, which are seen from internal and external factors. To check the validity and reliability of the instrument through confirmatory factors using the SEM (Structural Equation Modeling) analysis method by testing the latent relationship model of the latent variables and getting a model to answer the estimates From the results of the study it was found that the factors that influence the productivity and welfare of salt farmers in Tanoh Anoe village are education, work experience, land area, income, health, and living conditions. What does not affect the productivity and welfare of salt farmers in Tanoh Anoe village is labor, capital, raw materials, counseling, training and capital assistance.
\end{abstract}

Keywords: salt farmers, productivity, welfare level, production factors, government policies, SEM

\section{Introduction}

Indonesia is the largest archipelago country in the world with 17,508 islands and an area of $7,700,000 \mathrm{~km} \neg$. Indonesia has the 4th longest line in the world which is $+95,181 \mathrm{~km}$. Of the advantages possessed by the State of Indonesia as a maritime country, of course there are various abundant marine and fisheries potentials, but these potentials have not yet been explored optimally.

Agricultural development is defined as an integrated rural development strategy that is environmentally sound, aiming to create growth and gradual socio-economic change from agrarian, towards industrial agrarian (agro-industry). Development is an effort of the government to develop the economy and increase the income of the community can be done by developing businesses that are in the community, both in the agricultural sector, industrial sector or service sector.

One of the potentials of the marine and fisheries sector that can be extracted is salt. Salt is a basic need and daily consumption of Indonesian people. Salt is a strategic commodity, because in 
addition to being a basic necessity that is consumed by humans approximately $4 \mathrm{~kg}$ / year it is also used as industrial raw material [1]. Salt users are broadly divided into 3 (three) groups, namely (1) Salt for human consumption, (2) Salt for salting and various foods and (3) Salt for industry. In Indonesia, salt is produced by evaporating seawater on a piece of coastal land with the help of wind and sunlight as a source of evaporation energy. Meanwhile, the Ministry of Industry calculates that the national salt requirement in 2016 is estimated to be around 2.6 million tons and the industry sector that uses the most salt is the kostik (chlor alkali plant), various food and pharmaceutical industries.

High demand cannot yet be met in domestic production and must be imported. Whereas local salt has only been able to meet consumption needs. In meeting the basic needs of local salt, domestic production has not been able to meet their needs, so in meeting the basic needs of salt is still dependent on salt from abroad. Meeting the national salt needs so far has been done through self-production and imports. The great potential of salt from the sea does not provide sufficient national salt needs. With the potential and the carrying capacity of marine nature, Indonesia should be able to produce and meet its own salt needs. The area of salt reaches 33,625 ha and only around 17,625 ha $(52.4 \%)$ is used to produce salt. The largest salt fields in 9 provinces are Nanggroe Aceh Darusalam (-), West Java (2,787 ha, 1,746 ha utilized), Central Java (3,249 ha, 3,248 ha utilized) and East Java (13,047 ha, 9,713 ha utilized), Bali (used 20 ha), East Nusa Tenggara (9,740 ha, used 304 ha), West Nusa Tenggara (1,574 ha, utilized 1,052), South Sulawesi $(1,264$ ha, used 1,260 ha) and Southeast Sulawesi (2,000 ha, used $300 \mathrm{ha})$. The Province of Aceh has the potential of a very supportive marine resource, $\mathrm{NaCl}$ (Sodium Clorida) salt which is obtained by evaporation of sea water and other methods, and is safe to use as food. Iodine is one of the important micronutrients for the human body. Lack of these substances can cause a variety of disorders known as IDD (Sodium Deficiency Disorders). As a result of iodized salt deficiency, the most widely known is enlargement of the thyroid gland. Iodine is also very useful for preventing dwarfism, miscarriage and death after childbirth as well as impaired ability of the brain by decreasing the power of brain intelligence (IQ).

The largest salt-making areas in Aceh Province are in nine districts, which consist of Aceh Besar, Pidie, Pidie Jaya, North Aceh, East Aceh, Southwest Aceh, South Aceh, Aceh Tamiang and Bireun. Bireun Regency is a potential area for the development of salt-making businesses that can create jobs for people who live in this area. Bireun Regency is a regency located not far in the Malacca Strait so that the state of the land around the Lira Sira (Pondok Garam) contains a lot of salt. This has made many people around Bireun Regency work as salt farmers. They work individually on their lira sira (Pondok Garam) and only produce traditional salt. In Tanoh Anoe Village, Term District of Bireun District, the majority of salt farmers are women, who also play a role as housewives. This is caused by the desire of the housewife to increase household income, because the income earned by the husband is still lacking to meet household needs.

In this village the process of producing salt can be said to be still fairly traditional making, this can be seen from the community who still use boreholes to suck water directly into cooking stoves and fuel for cooking still use firewood, then cook until dry so that the granules are seen white crystalline color called salt. The price of salt produced by farmers is relatively cheap because it has not been mixed with iodine. In a day the farmer can produce salt reaching $150 \mathrm{~kg}$ the selling price of farmer salt is Rp.6,200 / kg with an operational cost of approximately Rp.260,000 / day for $45 \mathrm{~kg}$ of salt. If the current wholesale sale price of salt is Rp.6,200/ kg and then multiplied 
by the total production of $45 \mathrm{~kg}$, the gross income is Rp.279,000. minus the production costs of Rp.260,000, the profit is around Rp.19,000 if the average salt farmer produces 3 times a day, then the profit is not up to Rp.60,000. This makes the salt farmers overwhelmed in spending capital to produce salt.

Until now the results of salt production in Bireun Regency are still below expectations. Where the quality of salt itself is less attention. This is because the management method is still traditional and does not pay attention to the cleanliness of salt production itself. Besides the very high production costs. By looking at the situation, the salting process in Bireun Regency needs to be improved, namely by shifting to the salting technology.

The formulation of the problem in this study are:

1. Does Demography affect Productivity in Tanoh Anoe Village, Kecamatan Term Bireun-Aceh District.

2. Does demography affect the welfare level of Salt Farmers in Tanoh Anoe Village, Kecamatan Term Bireun-Aceh.

3. Does the Production Factor affect Productivity in the Tanoh Anoe Village, Kecamatan Term Bireun-Aceh District.

4. Does the Production Factor affect the Welfare Level of Salt Farmers in Tanoh Anoe Village, Kecamatan Term Bireun-Aceh District.

5. Does Productivity affect the Level of Welfare of Salt Farmers in Tanoh Anoe Village, Kecamatan Term Bireun-Aceh District.

The purpose of this study is to analyze the partial and simultaneous influence of demographics and production factors on the productivity and welfare of salt farmers in Tanoh Anoe Village, Kecamatan Term Bireun-Aceh Regency.

\section{Productivity}

Productivity is an important factor in realizing the success of increasing the income of farmers themselves, besides that it can also produce farm products that are free of chemicals whose impacts are natural and environmental damage [2]. Sulaeman [3] states productivity reflects a good work ethic of farmers, both in terms of mental and others. Thus, the peasants who plunge directly try to improve their performance with various policies that are efficient, able to increase their productivity. In addition, there are many factors that cause the decline in the agricultural sector as seen from its productivity. In a study conducted by Subiyanto [4] states that there is a real relationship between formal education, farming experience, extensive land use and working capital, labor and the application of technology to farm productivity.

Supriyanto and Machfudz [5] say that productivity implies a comparison between the results achieved (output) with the overall resources used. The factors that affect productivity can be classified in three groups, namely:

- Quality and physical abilities of employees is including levels of education, work motivation, work ethic, mental and physical abilities of employees and training.

- Supporting facilities regarding the work environment, including technology and production methods, facilities and equipment used, the level of occupational safety and health as well as the atmosphere in the work environment itself and concerning employee welfare which is reflected in the wage system and social security as well as guarantees continuity of work. 
- Supra-facility, the company's activities are always influenced by what happens outside. As factors of production to be used, marketing prospects, taxation, licensing, environment and others. Government policies in the field of export-import, restriction and supervision also affect the scope of company leadership and the course of activities in the company.

The indicators of the Productivity variable, among others:

- Location

- According to Griffin, location is the physical position or geographical location of a facility and must be determined by the needs of the organization.

- Education

- Notoatmodjo argues education is a process of developing capabilities in the direction desired by the organization concerned. According to Admodiwirio education is learning prepared to improve the implementation of work in the future or to improve someone to be able to accept a responsibility in new tasks.

- Work experience

- According to Handoko work experience is the mastery of employees' knowledge and skills measured by the length of work, the level of knowledge and skills possessed by employees. Experience is only gained through the workplace.

\section{Prosperity Level}

According to the Central Statistics Agency [6] in Rahmad Sembiring [7] there are eight indicators used to determine the level of welfare, namely: income, consumption, family expenses, living conditions, housing facilities, health of family members, easy access to health services, the ease of entering children into education and the ease of transportation.

Increasing community welfare is the essence of national development. This level of community welfare reflects the quality of life of a family. A family with a higher level of welfare means having a better quality of life, so that in the end the family is able to create better conditions to improve their welfare. According to Kusnadi [8] it is difficult to improve the welfare of a number of internal and external factors.

Furthermore it is also said that population education is often used as an indicator of the progress of a nation and an indicator in an effort to improve people's welfare. Education in today's life has been considered as a basic need that cannot be postponed. An overview of the level of welfare of the people can also be seen from the conditions and facilities of their residence. Housing is one of the most important basic needs besides food and clothing to meet decent needs. In addition, nutritional factors are also a major indicator in the nutritional and consumption components used in describing the lower standard of living of the community. Furthermore, it is said that the economic level is still low causing that the community has not been able to obtain community services. Farmers' Welfare Level is an analytical calculation of all data in each welfare indicator which are all related to the socioeconomic conditions of the farmer's household.

\section{Demography}

Demography is the study of population changes regarding changes in number, distribution and composition, or population measurement tools. These changes are influenced by changes in the main components of population growth, namely, fertility, mortality and migration. Overall 
demographics give a picture of the behavior of the population, both in the aggregate and in groups. Population can be grouped according to certain characteristics, such as age groups, socioeconomic characteristics, and distribution or distribution of residence where this grouping is very useful for various purposes and objectives. Demographic characteristics have characteristics including age / age, sex, marital status, number of family members, employment, type of work [9].

\section{Production Factor}

Agricultural production is the results obtained as a result of the operation of several factors of production at once. From some of the notions put forward by the experts, the authors conclude that production in agriculture, which is a result obtained from agricultural land in a certain time is usually measured in units of weight tons or $\mathrm{kg}$ indicates the great potential of agricultural commodities. Factors of production indeed determine the size of the production obtained [10].

\section{Conceptual Framework}

Based on the existing problems, then a framework can be made about the influence of demographics and factors of production on the productivity and welfare of salt farmers in Tanoh Anoe village, Kecamatan sub-district, Bireun-Aceh District.

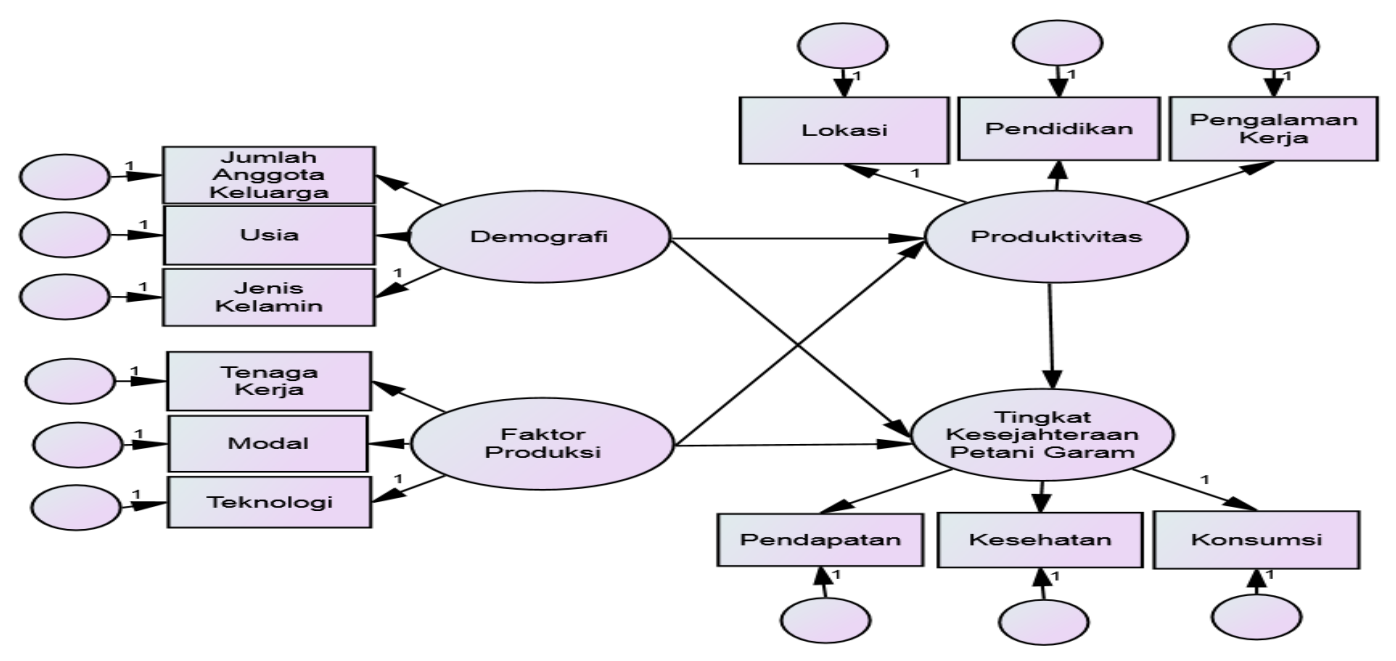

Fig 1. Conceptual Framework for Structural Equation Modeling (SEM) 
The hypothesis is a temporary answer, the truth of which remains to be proven. This temporary answer is still the starting point for further research. Based on the formulation of the problem, the hypothesis of this study is:

1) Demography influences Productivity in Tanoh Anoe Village, Kecamatan Term BireunAceh District.

2) Production Factors affect Productivity in Tanoh Anoe Village, Kecamatan Term BireunAceh District.

3) Demography influences the level of welfare of Salt Farmers in Tanoh Anoe Village, Kecamatan Term Bireun-Aceh District.

4) Production Factors affect the Welfare Level of Salt Farmers in Tanoh Anoe Village, Kecamatan Term Bireun-Aceh District.

5) Productivity affects the level of welfare of Salt Farmers in Tanoh Anoe Village, Kecamatan Term Bireun-Aceh.

\section{Research Method}

This type of research is causal (causal) research, Umar [11] states that causal design is useful for analyzing how a variable affects other variables, and is also useful in experimental research where the independent variable is treated in a controlled manner by the researcher to see its impact on the dependent variable directly. This research was conducted in the village of Tanoe Anoe, Kecamatan Term Bireun-Aceh district with the time of the study planned from September 2018 to February 2019

According to Sugiyono [12] "Population is the area of generalization consisting of objects / subjects that have certain qualities and characteristics". According to Sugiyono [12]: "Samples are part of the number and characteristics possessed by the population". The population in this study was 400 families. The sample in this study was Salt Farmers. How to take samples using the Slovin formula in Husein Umar [11], as follows:

$$
n=\frac{N}{1+\left(N(e)^{2}\right)}
$$

$\mathrm{n}=$ sample size

$\mathrm{N}=$ population size

$\mathrm{e}=$ error rate.

The error rate is set at $5 \%$.

The following calculation is the sample size:

$$
n=\frac{400}{1+(400 \times 0.0025)}
$$




$$
\begin{aligned}
& n=\frac{400}{1+1} \\
& n=\frac{400}{2} \\
& n=200 \\
& \mathrm{n}=200 \text { responden. }
\end{aligned}
$$

So from 200 samples can be selected based on criteria as many as 200 families of respondents' productivity and welfare of salt farmers.

The variables operated in this study are the variables contained in the hypothesis that have been formulated. To provide a clear answer, it is necessary to give a definition of the variables to be examined in order to facilitate the making of the questionnaire as follows:

Table 1. Operationalization of Variables

\begin{tabular}{lll}
\hline Variables & \multicolumn{1}{c}{ Description } & Scale \\
\hline Demografi & $\begin{array}{l}\text { Social Demography is the dynamics of human } \\
\text { population including the size, structure, and } \\
\text { distribution of the population, as well as how the } \\
\text { population changes every time due to birth, death, } \\
\text { migration, and aging. }\end{array}$ & Likert \\
Faktor Produksi & $\begin{array}{l}\text { Production Factors are resources used in the process } \\
\text { of producing goods and services. }\end{array}$ & Likert \\
(X2) & $\begin{array}{l}\text { Productivity is the desire and human effort to always } \\
\text { improve the quality of life and livelihood in all }\end{array}$ & Likert \\
(Y1) & $\begin{array}{l}\text { fields. } \\
\text { Telfare level is a system of life and livelihood of a } \\
\text { person both socially material and spiritual which is } \\
\text { (Y2) }\end{array}$ & Likert \\
& peace of mind and body, so as to meet the needs \\
jasmaniah, rohaniah dan sosialnya. & \\
\hline
\end{tabular}

Data collection techniques used in the form of primary data and secondary data. Primary data obtained from interviews directly from respondents with the help of a questionnaire that has been prepared. Besides primary data, secondary data are used as supporting data in this study. Secondary data was obtained from related institutions, such as the District Office, Village Hall, relevant Dinas and other relevant sources. Data collected from the questionnaire was then tested for validity and reliability.

For data analysis from this study Structural Equation Modeling (SEM) was used. SEM is a statistical modeling technique that is very cross-sectional, linear and general. Included in this, SEM is factor analysis (factor analysis), path analysis (path analysis) and regression (regression). 


\section{Results and Discussion}

\section{1) Overview of the Kecamatan District Area}

The term sub-district covers an area of 8,118 hectares consisting of 46 villages with a population of 29,084 people and a population density of 358 people. The boundaries of the North Sub-District of the Malacca Strait, South of the Peusangan District, the West of the Kuala District, the East of the Kuta Blang District and the Gandapura District.

Table 2. Broad District Term by Village

\begin{tabular}{|c|c|c|}
\hline No & Desa & $\begin{array}{l}\text { Luas Lahan } \\
\text { (Ha) }\end{array}$ \\
\hline 1 & Desa Pulo U & 250 \\
\hline 2 & Desa Abeuk Jaloh & 93 \\
\hline 3 & Desa Pulo Seuna & 138 \\
\hline 4 & Desa Pulo Blang & 79 \\
\hline 5 & Desa Pulo Iboih & 465 \\
\hline 6 & Desa Pulo Reudeup & 197 \\
\hline 7 & DesaGampong Meulinteung & 215 \\
\hline 8 & Desa Lamkuta & 140 \\
\hline 9 & Desa Rusep Ara & 265 \\
\hline 10 & Desa Lueng & 140 \\
\hline 11 & Desa Ruseb Dayah & 239 \\
\hline 12 & Desa Kambuek & 98 \\
\hline 13 & Desa Bada Timur & 100 \\
\hline 14 & Desa Bada Barat & 95 \\
\hline 15 & Desa Barat Lanyan & 190 \\
\hline 16 & Desa Geundot & 85 \\
\hline 17 & Desa Meunasah Krueng & 230 \\
\hline 18 & Desa Paya Bieng & 130 \\
\hline 19 & Desa Jangka Alue & 142 \\
\hline 20 & Desa Jangka Keutapang & 149 \\
\hline 21 & Desa Lampoh Rayeuk & 130 \\
\hline 22 & Desa Lhok Bugeng & 136 \\
\hline 23 & Desa Linggong & 100 \\
\hline 24 & Desa Alue Baya & 281 \\
\hline 25 & Desa Tanoh Anoe & 120 \\
\hline
\end{tabular}




\begin{tabular}{|c|c|c|}
\hline No & Desa & $\begin{array}{l}\text { Luas Lahan } \\
(\mathrm{Ha})\end{array}$ \\
\hline 26 & Desa Tanjong & 95 \\
\hline 27 & Desa Jangka Alue Bie, & 120 \\
\hline 28 & Desa Alue Bie Pusong & 70 \\
\hline 29 & Desa Jangka Mesjid & 120 \\
\hline 30 & Desa Jangka Alue U & 320 \\
\hline 31 & Desa Pante Peusangan & 213 \\
\hline 32 & Desa Bugak Krueng & 171 \\
\hline 33 & Desa Bugak Mesjid & 175 \\
\hline 34 & Desa Krueng Mate & 186 \\
\hline 35 & Desa Bugeng & 237 \\
\hline 36 & Desa Kuala Ceurape & 174 \\
\hline 37 & Desa Alue Bayeu Utang & 152 \\
\hline 38 & Desa Ulee Ceue & 159 \\
\hline 39 & Desa Alue Kuta & 325 \\
\hline 40 & Desa Punjot & 284 \\
\hline 41 & Desa Pulo Pineung Mns. Dua & 161 \\
\hline 42 & Desa Bugak Blang & 114 \\
\hline 43 & Desa Pante Sukon & 218 \\
\hline 44 & Desa Pante Paku & 255 \\
\hline 45 & Desa Pante Ranub & 160 \\
\hline 46 & Desa Alue Buya Pasi & 202 \\
\hline
\end{tabular}

Source: Central Bureau of Statistics Bireun

From the table above, it can be seen that Tanoh Anoe Village, Kecamatan District which has an area of 120 hectares, when seen Tanoh Anoe Village has an area not too wide and not too small compared to other villages. The village that has a large land area is Pulo Iboih Village with an area of $465 \mathrm{Ha}$, while the village that has a small land area is Alue Bie Pusong Village with an area of $90 \mathrm{Ha}$.

To find out the results of hypothesis testing is done by looking at the value of probability (probability) or by looking at the significance of the relationship of each research variable. The criterion is that if $\mathrm{P}<0.05$, the relationship between variables is significant and can be further analyzed, and vice versa. Therefore, by looking at the probability number (p) on the output of the overall path shows a significant value at the $5 \%$ level or the standardize value must be more greater than 1.96 (> 1.96). (If you use the value of the comparison value with $t$ table, it means that 
the value of $t$ count is above 1.96 or $>1.96$ or $t$ count is greater than $t$ table). AMOS 22 can set the following criteria for accepting and rejecting hypotheses:

If $\mathrm{P}>0.05$ then $\mathrm{H} 0$ is accepted (not significant)

If $\mathrm{P}<0.05$ then $\mathrm{H} 0$ is rejected (significant)

The hypothesis in this study is divided into 5 (five) tests, namely:

1) Production factors affect productivity in Tanoh Anoe Village, Kecamatan Term Bireun-Aceh District.

2) Production factors have an impact on the level of welfare in Tanoh Anoe Village, Kecamatan Term Bireun-Aceh Regency.

3) Government policies affect productivity in Tonoh Anoe Village, Kecamatan Term Bireun-Aceh District.

4) Government policies affect the level of welfare in Tanoh Anoe Village, Kecamatan Term Bireun-Aceh District.

5) Productivity influences the level of welfare in Tanoh Anoe Village, Kecamatan Term Bireun-Aceh District.

Table 3. Hasil estimasi C.R (Critical Ratio) dan P-Value

\begin{tabular}{|c|c|c|c|c|c|c|c|}
\hline & & & Estimate & S.E. & C.R. & $\mathrm{P}$ & Label \\
\hline PDV & $<---$ & FP & .058 & .096 & .598 & .550 & par_9 \\
\hline PDV & $<---$ & $\mathrm{KP}$ & .034 & .142 & .239 & .811 & par_11 \\
\hline TK & $<---$ & FP & -.157 & .093 & -1.697 & .090 & par_10 \\
\hline TK & $<---$ & $\mathrm{KP}$ & -.394 & .145 & -2.727 & .006 & par_12 \\
\hline TK & $<---$ & PDV & .279 & .078 & 3.575 & $* * *$ & par_13 \\
\hline fp3 & $<---$ & FP & 1.000 & & & & \\
\hline $\mathrm{fp} 2$ & $<---$ & FP & 1.305 & .128 & 10.213 & $* * *$ & par_1 \\
\hline fp1 & $<---$ & FP & 1.665 & .164 & 10.164 & $* * *$ & par_2 \\
\hline kp3 & $<---$ & KP & 1.000 & & & & \\
\hline $\mathrm{kp} 2$ & $<---$ & $\mathrm{KP}$ & 1.099 & .193 & 5.690 & $* * *$ & par_3 \\
\hline $\mathrm{kp} 1$ & $<---$ & $\mathrm{KP}$ & 1.649 & .291 & 5.663 & $* * *$ & par_4 \\
\hline pdv1 & $<---$ & PDV & 1.000 & & & & \\
\hline pdv2 & $<---$ & PDV & .795 & .078 & 10.183 & $* * *$ & par_5 \\
\hline pdv3 & $<---$ & PDV & 1.113 & .099 & 11.206 & $* * *$ & par_6 \\
\hline $\mathrm{tk} 1$ & $<---$ & TK & 1.000 & & & & \\
\hline $\mathrm{tk} 2$ & $<---$ & TK & 1.011 & .056 & 17.961 & $* * *$ & par_7 \\
\hline tk3 & $<---$ & TK & .897 & .059 & 15.232 & $* * *$ & par_8 \\
\hline
\end{tabular}

Sumber : Lampiran Amos 


\section{Discussion}

The results of the analysis using structural equation modeling (SEM) with AMOS 22 software prove that there is no significant effect of production factors on productivity in Tanoh Anoe Village, Kecamatan Term Bireun-Aceh District.

The insignificance of production factors on productivity is due to the still poor production factors in Tanoh Anoe Village, for example, lack of labor and the majority are elderly housewives with low education, low education levels are one of the factors inhibiting technological innovation in society. According to Soehardjoe and Patoeng [13] stated that education generally influences farmers' ways and mindset more dynamically. The higher the farmer's level of education, the more efficient he works and the more he participates in training in ways that are more productive and more profitable.

This is supported by the theory, Soehardjoe and Patoeng, Banoewidjoyo [14] suggest that the level of education possessed by the workforce can not only increase productivity and quality of work done, but at the same time accelerate the process of completion of the work undertaken. It is clear that the production factor of productivity is not significant because the salt farmer workforce in Tanoh Anoe Village is still relatively low, thus making productivity in Tanoh Anoe Village also low.

\section{The Influence of Production Factors on the Welfare Level}

The results of the analysis using structural equation modeling (SEM) with AMOS 22 software prove that there is no significant influence of production factors on the level of welfare in Tanoh Anoe Village, Kecamatan Term Bireun-Aceh District.

The insignificance of the factor of production on the level of welfare due to high capital with low income will affect the welfare level of farmers. Capital is the most fundamental problem that is often faced by farmers. Capital is often an obstacle for a farmer in conducting farming. Capital limitations also make the quantity and quality of results obtained by farmers not optimal. These capital problems are also the main cause of many farmers living below the poverty line (not yet prosperous). The problem will arise how farmers get capital to restart their farming, to purchase raw materials such as seeds, wood and others.

This is supported by Soeharjo and Patong's theory in Risti Diana Putri [15] stating that income is a remuneration from the cooperation of factors of production, land, capital, labor, and management services. Farm income is used by farmers to meet the needs of his family's life, maintain his farm and even expand it.

\section{Effect of Government Policy on Productivity}

The results of the analysis using structural equation modeling (SEM) with AMOS 22 software prove that there is no significant effect of government policy on productivity in Tanoh Anoe Village, Kecamatan Term Bireun-Aceh District.

The insignificance of the government's policy on productivity is due to the lack of counseling and training from the government for salt farmers in Tanoh Anoe Village so that it is still constrained for farmers to develop opportunities to sell their produce, and the lack of capital assistance provided by the government to farmers so that it affects productivity the farmers. 


\section{Effect of Government Policy on Welfare Level}

The results of the analysis using structural equation modeling (SEM) with AMOS 22 software prove that there is no significant effect of government policies on the level of welfare in Tanoh Anoe Village, Kecamatan Term Bireun-Aceh District.

The insignificance of government policies towards the level of welfare is in line with the opinion of Simatupang, Zin, Salim, Thoyib states that government policies on welfare do not have a significant effect, because government policies on welfare levels cannot affect the farm family economy.

\section{Effect of Productivity on Welfare Level}

The results of the analysis using structural equation modeling (SEM) with AMOS 22 software prove that there is a significant effect of productivity on the level of welfare in Tanoh Anoe Village, Kecamatan Term Bireun-Aceh District.

With the significant productivity of the level of welfare of farmers in the village of Tanoh Anoe due to the long experience owned by farmers so as to produce salt is very easy, according to Soekartawi [16] a long experience of farming will make farmers more careful in the decision making process, the intended decision is to make a good product and not a failed product. So that with a good product to be marketed makes farmers 'income increases. In line with the opinion of Widnyana [2] productivity is an important factor in realizing the success of increasing farmers' income itself, but it also can produce farm products that are free of chemicals whose impact on natural and environmental damage.

What affects the welfare level of salt farmers is the area of land, according to Sajogyo that the larger the area of farming land, the greater the percentage of production income, thus that land area plays an important role on the income of farmers.

\section{Conclusions and Suggestions}

\section{Conclusion}

The conclusions that can be poured in this study are,

1) Production factor is not a significant effect on the productivity of salt farmers in the village of Tanoh Anoe, the sub-district of Bireun-Aceh District.

2) The production factor is not a significant effect on the level of welfare of salt farmers in Tanoh Anoe village, Bireun-Aceh District.

3) Government policy has insignificant influence on the productivity of salt farmers in Tanoh Anoe village, Bireun-Aceh District.

4) Government policy does not significantly influence the level of welfare of salt farmers in the village of Tanoh Anoe, the sub-district of Bireun-Aceh District.

5) Productivity significant influence on the level of welfare of salt farmers in the village of Tanoh Anoe sub-district of Bireun-Aceh District. 


\section{Suggestion}

Based on the discussion above it is known that the factors of production and government policies are not significant to affect the productivity and welfare of salt farmers in the village of Tanoh Anoe sub-district, Bireun-Aceh District. Suggestions obtained from the results of this study are:

1) The insignificance of production factors on productivity in Tanoh Anoe village, the district of Bireun-Aceh district, is due to the low labor, capital and raw materials so that the farmers are not yet productive. In order to increase the labor productivity of salt farmers must have formal education and long working experience so as to increase production results with better quality, land area also affects production results and can increase the productivity of farmers.

2) The insignificance of production factors on the level of welfare in the Tanoh Anoe village, the district of Bireun-Aceh district, is due to the low labor, capital and raw materials so that salt farmers are still not yet prosperous. Workers greatly affect the level of welfare the more labor the more the results of production and income are increasing, and the capital spent to buy raw materials can be fulfilled. In addition, farmers must be able to arrange time to rest so that health can be maintained properly.

3) The insignificance of government policies on productivity in Tanoh Anoe village, the district of Bireun-Aceh district, which is caused by the government's lack of attention to salt farmers in Tanoh Anoe village so that the lack of counseling (empowerment), training and capital assistance provided by the government has resulted in the low productivity of salt farmers. . Salt farmers in Tanoh Anoe village really need counseling (empowerment) to facilitate the marketing of products, and training for farmers who have less work experience or training for making more modern salt.

4) The insignificance of government policies towards the level of welfare in the village of Tanoh Anoe, the sub-district of Bireun-Aceh District, makes reference to the government to pay more attention in the form of useful extension (empowerment), training to produce higher quality salt so that it is easy to market and farmers really need capital from the government because, capital assistance provided is the right solution in the problem of poverty reduction of salt farmers in the village of Tanoh Anoe.

5) Significant productivity of the level of welfare of salt farmers in Tanoh Anoe village, Bireun-Aceh district-run district to maintain education, work experience and land area in order to increase the level of welfare of salt farmers. With formal education, long work experience and sufficient land area can affect farmers' incomes, not just income and better living conditions. While more income farmers can save for food and clothing needs.

\section{References}

[1] Kementerian Kelautan dan Perikanan, Keputusan Menteri Kelautan dan Perikanan Republik Indonesia No.Kep 18/Men/2011 tentang Pedoman Umum Minapolitan, Kementerian Kelautan dan Perikanan, Jakarta. (2011). 
[2] Widnyana, I Ketut. Upaya Meningkatkan Pendapatan Petani Melalui Pendamping Penerapan Iptek Penerapan Produktivitas Padi Berbasis Organik. E-Jurnal Pertanian Universitas Mahasaraswati Denpasar. 2(2) Ha l: 35-43. (2011).

[3] Sulaeman, Ardika. "Pengaruh Upah dan Pengalaman Kerja Terhadap Produktivitas Karyawan Kerajinan Ukiran Kabpaten Subang,” Jurnal Trikonomika, 05 (Juni), 91-100. (2014).

[4] Subiyanto, Ibnu. Metodologi Penelitian (Manajemen dan Akuntansi). Edisi Ketiga. Penerbit: Unit Penerbit dan Percetaka Akademi Manajemen dan Perusahaan (UPP AMP) YPKN. (2003).

[5] Supriyanto, Achmad Sani dan Machfudz Mansyuri. Metodologi Riset Manajemen Sumber Daya Manusia. Malang: UIN-MALIKI PRESS. (2010).

[6] Badan Pusat Statistik. Memahami Data Strategis yang Dihasilkan BPS. Jakarta. (2007).

[7] Sembiring, Rahmad. Pengaruh Nilai Tukar Nelayan (Pendapatan Nelayan, Pendapatan Non Nelayan, Pengeluaran Nelayan, Pengeluaran Non Nelayan) Terhadap Kesejahteraan Masyarakat (Pendidikan, Kesehatan, Kondisi Fisik Rumah) di Desa Pahlawan. Jurnal JEPA. Batu Bata. Universitas Pembangunan Panca Budi. (2017).

[8] Kusnadi. Akar Kemiskinan Nelayan. PT LKIS Pelangi Aksara. Jakarta. (2003).

[9] Mulyadi. Akuntansi Biaya. Edisi Kelima. Yogyakarta: UPPAMP YKPN Universitas Gajah Mada. (2005).

[10] Soekartawi. Agribisnis: Teori dan Aplikasinya. Jakarta: PT Raja Grafindo Persada. 238 hal. (2010).

[11] Husein, Umar. Metode Penelitian Untuk Skripsi dan Tesis Bisnis, Jakarta. PT Raja grafindo Persada. (2008).

[12] Sugiyono. Metode Penelitian Kuantitatif, Kualitatif dan $R \& D$. Bandung: Alfabeta. (2011).

[13] Soeharjo, A dan Patong. Faktor-faktor Produksi Padi. Jakarta. Penebar Swadaya. (1994).

[14] Banoewidjoyo. Pengembangan Pertanian Usaha Nasional. Jakarta. Swadaya. (2002).

[15] Putri, Risti Diana. Analisis Pendapatan dan Curahan Kerja Rumah Tangga Petani Wortel di Desa Sukatani Kecamatan Pacet Kabupaten Cianjur. [Skripsi] Institut Pertanian Bogor.111 hal. (2008).

[16] Soekartawi. Analisis Usaha tani. Jakarta. Universitas Indonesia. (2006). 